\title{
STUDY OF MORPHOLOGICAL VARIATIONS OF THYROID GLAND IN ADULT HUMAN CADAVERS
}

\author{
Saurjya Ranjan Das ${ }^{1}$, Sreepreeti Champatyray², Gyana Ranjan Nayak³, Biswa Bhusan Mohanty ${ }^{4}$ \\ ${ }_{1}^{1}$ Assistant Professor, Department of Anatomy, IMS and SUM Hospital, Bhubaneswar, Odisha, India. \\ 2Senior Lecturer, Department of Oral Pathology, Institute of Dental Sciences, [Siksha 'O' Anusandhan] Odisha, India. \\ ${ }_{3}^{3}$ Associate Professor, Department of Anatomy, IMS and SUM Hospital, Bhubaneswar, Odisha, India. \\ ${ }_{4}^{4}$ Associate Professor, Department of Anatomy, IMS and SUM Hospital, Bhubaneswar, Odisha, India.
}

\section{ABSTRACT}

\section{BACKGROUND}

The thyroid is a highly vascular gland situated in front of the neck. It consists of two symmetrical lobes united by an isthmus that lie in front of $2^{\text {nd }}, 3^{\text {rd }}$ and $4^{\text {th }}$ tracheal rings. The thyroid gland is the first endocrine gland to develop and takes its final shape and position at the end of the 7 th week in front of the trachea.

Aims and Objectives- The thyroid gland is a highly vascular endocrine gland situated in front of the neck. It consists of right and left lobes joined together by a narrow isthmus lying opposite to second, third and fourth tracheal ring. A number of morphological variation and developmental anomalies have been reported, which has numerous clinical and surgical implications.

\section{MATERIALS AND METHODS}

This is a descriptive study done during routine dissection of head and neck region in 32 cadavers in the Department of Anatomy, IMS and SUM Hospital of around 30 to 65 years of age for a period of 4 years. All the variations found were noted down.

\section{RESULTS}

It was found that the isthmus of the thyroid gland was absent in two cadavers and the two lateral lobes were completely separated. This absence of isthmus may be due to abnormality in development of thyroid gland, which may be associated with other type of disorganogenesis such as absence of lobe or presence of ectopic thyroid tissue.

\section{CONCLUSION}

Agenesis of thyroid isthmus has clinical, phylogenetic and surgical significance. The embryogenesis of such anomalies is discussed.

\section{KEY WORDS}

Thyroid, Isthmus, Levator Glandulae Thyroideae.

HOW TO CITE THIS ARTICLE: Das SR, Champatyray S, Nayak GR, et al. Study of morphological variations of thyroid gland in adult human cadavers. J. Evolution Med. Dent. Sci. 2018;7(23):2807-2810, DOI: 10.14260/jemds/2018/633

\section{BACKGROUND}

The thyroid is a highly vascular gland situated in front of the neck. It consists of two symmetrical lobes united by an isthmus that lie in front of $2^{\text {nd }}, 3^{\text {rd }}$ and $4^{\text {th }}$ tracheal rings. The normal size of each lobe of the thyroid gland is $5 \mathrm{cms}$ long. Its greatest transverse and antero-posterior extent being $3 \mathrm{cms}$ and $2 \mathrm{cms}$ respectively.[1] The isthmus measures about 1.25 cms transversely as well as vertically and is usually placed anterior to the second and third tracheal cartilages. [2] It gives a ' $\mathrm{H}$ ' shaped appearance to the gland. It has a fibrous capsule with a true capsule formed by condensation of fibrous stroma of the gland and a false capsule derived from the splitting of the pretracheal fascia. The false capsule is thickened to form the ligament of Berry, which connects the medial surface of lateral lobe of the gland with cricoid cartilage. Each lateral lobe is pear shaped. The anastomosis between the two superior thyroid artery is present in the upper border and the veins emerge from the lower border.

'Financial or Other Competing Interest': None.

Submission 28-04-2018, Peer Review 21-05-2018,

Acceptance 28-05-2018, Published 04-06-2018.

Corresponding Author:

Dr. Saurjya Ranjan Das,

Department of Anatomy,

IMS and SUM Hospital,

Bhubaneswar,

Odisha, India.

E-mail: saurjyadas@gmail.com

DOI: $10.14260 /$ jemds $/ 2018 / 633$
The thyroid gland is the first endocrine gland to develop and takes its final shape and position at the end of the 7 th week in front of the trachea. [3]

It begins to form about 24 days after fertilisation from a median endodermal thickening in the floor of the primitive pharynx near junction of first and second pharyngeal arches between tuberculum impar and copula respectively. ${ }^{[4,5]}$ The depression at the origin of the diverticulum is called as foramen caecum. The blind end of the duct divides and proliferates to form the two lobes of the thyroid gland. Sometimes a small portion of the gland projects upwards from the isthmus called as pyramidal lobe. It may be attached to the inferior border of hyoid bone by a fibrous tissue called as Levator Glandulae Thyroideae (LGT) supplied by external laryngeal nerve.[6] When muscle fibres are present, it is named musculus levator glandulae thyroideae.[7]

A wide range of morphological variations of thyroid gland has been found. It includes persistence of pyramidal lobe, thyroglossal cyst, agenesis of thyroid gland, agenesis of isthmus, ectopic thyroid tissue etc.

The anomalies of the development of the thyroid gland distort the morphology of the gland and they may cause clinical functional disorders and various thyroid illnesses. ${ }^{[8]}$ The knowledge of the various developmental anomalies of the gland and the variations in the neurovascular relations will help the surgeons in the better planning of a safe and effective surgery. 


\section{MATERIALS AND METHODS}

Aim of our study was descriptive study, the morphological variations of the thyroid lobe and isthmus and the neurovascular relation. The study was carried out for four years in the Department of Anatomy, IMS and SUM Hospital. The total number of cadaver was formalin fixed 32 cadavers, out of which 24 males and 8 females of age between 30 and 65 years. The neck of each cadaver was observed clearly to find out if any surgical intervention was done of the cadavers. Then dissection of the neck was done on the midline to explore the thyroid gland and variations were observed in the morphology of the thyroid gland.

We observed the different variations in the specimen. Various parameters like length of the lateral lobes, height of isthmus, presence of pyramidal lobe and absence of isthmus were studied.

\section{RESULTS}

The average length of the right lobe of thyroid gland was 5.10 $\mathrm{cms}$ and that of the left lobe was $4.65 \mathrm{~cm}$. The average height of the isthmus was $2.15 \mathrm{cms}$. The Pyramidal lobe was found in 4 specimens of the thyroid glands. Four out of the 32 cadavers dissected showed no glandular tissue in the region of the isthmus of thyroid gland. Grossly, only the pre-tracheal fascia connecting the right and left lobes of the thyroid gland was observed. In first case, a male cadaver of around 50 years showed complete absence of isthmus and the two lobes were distantly apart (Figure 1).

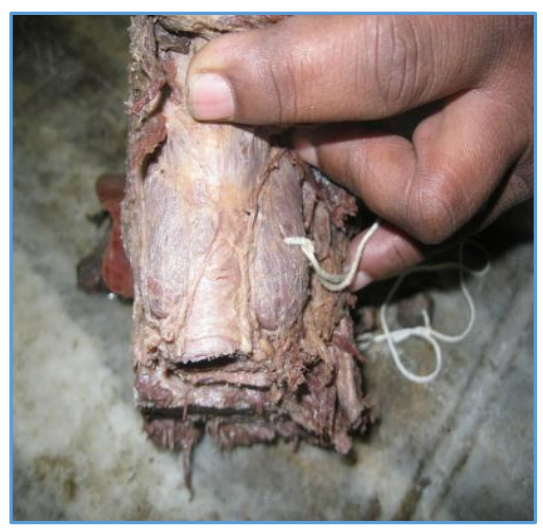

Figure 1. Showing Complete Absence of Isthmus

In second case, thyroid gland in female cadaver showed a large right lobe and smaller left lobe with presence of pyramidal lobe connected to the hyoid bone through levator glandulae thyroideae on right side (Figure 2).

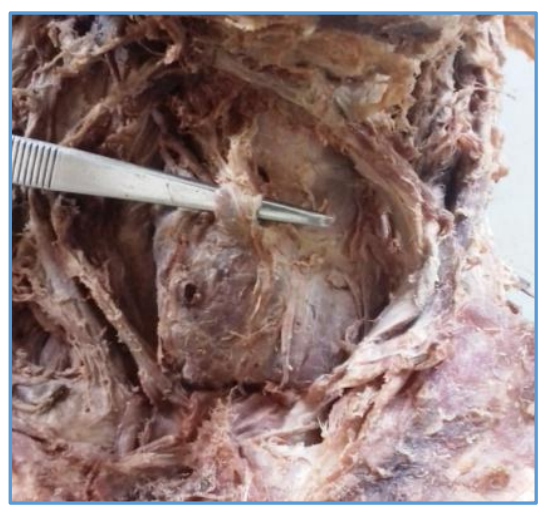

Figure 2. Showing Pyramidal Lobe with LGT on Right Side
There are 4 specimens which had pyramidal lobe with levator glandulae thyroideae on left side, which are predominately muscular (Figure 3).

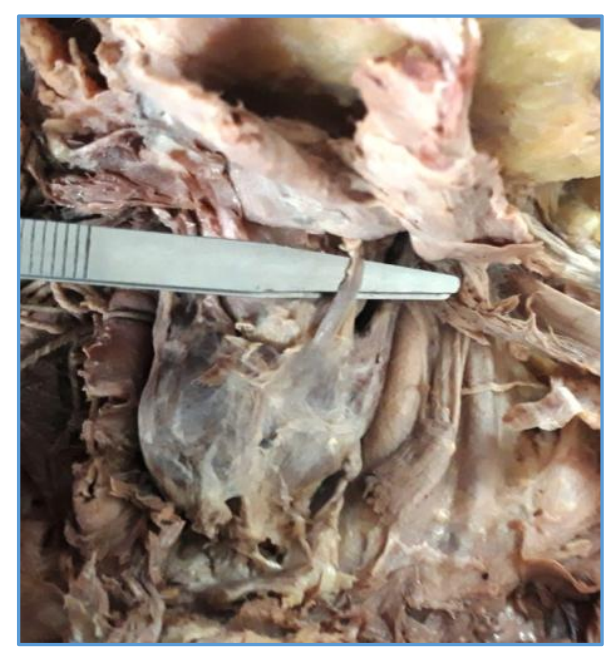

Figure 3

In our study, the male-to-female ratio of incidence of variation was $2: 1$.

Out of 32 cadavers $30 \%$ of the specimens showed variation, out of which $12.5 \%$ showed absence of isthmus, $12.5 \%$ showed unilateral glandulae thyroideae on the left side and another $5 \%$ on the right side. There is no presence of levator glandulae thyroideae on midline and bilaterally.

\section{DISCUSSION}

Agenesis of the thyroid isthmus can also be defined as the complete and congenital absence of the thyroid isthmus.[9] The studies done by Pastor et al on Caucasian cadaver, agenesis of isthmus of thyroid gland with enlarged lobes was reported. Absence of isthmus is indeed quite rare in humans.[10]

Phylogenetically, the isthmus may be absent in amphibians, birds and among mammals- monotremes, certain marsupials, cetaceans, carnivores and rodents. In rhesus monkey (Macacus rhesus), the thyroid glands are normal in position but there is no isthmus.[9]

Usually, agenesis of isthmus is difficult to determine unless the patient reports for other thyroid illness. Agenesis of isthmus does not cause clinical symptoms by itself and diagnosis is secondary due to the existence of other thyroid pathologies. This may be due to mutation of genes associated with thyroid gland. Recent literature suggests that chromosome 22 plays a major role in the thyroid development.[11]

The incidence of agenesis of isthmus has been reported to vary from 3 to 33\% as reported by various authors as shown in Table 1. Marshall documented the variations in the gross structure of the thyroid gland in 60 children, varying in age from a few weeks to 10 years and the absence of the isthmus was reported to be $10 \%$ in this group.[12] Ranade et al reported absence of isthmus in 35 out of 105 cases (33\%), of which 8 were female cadavers. ${ }^{[13]}$ According to the study by Braun et al, the isthmus was missing in 4 cases of the 58 cadavers (6.9\%) they studied.[14] Won and Chung have reported that in $3 \%$ of the cases studied, the isthmus was absent and the lateral lobes of the thyroid were separated.[15] 
The incidence in Northwest Indians is reported to be $7.9 \%$ in gross specimens.[16] In our study, the incidence was a little higher at $12.5 \%$.

\begin{tabular}{|c|c|c|}
\hline Sl. No. & Author and Year & Incidence \\
\hline 1 & Marshall, 1895[12] & $10 \%$ \\
\hline 2 & Kukarni and Kadam, 2001[17] & 1 case \\
\hline 3 & Won and Chung, 2002[15] & $3 \%$ \\
\hline 4 & Harjeet et al, 2004[16] & $7.9 \%$ \\
\hline 5 & Pastor et al, 2006[9] & 1 case \\
\hline 6 & Braun et al, 2007[14] & $6.9 \%$ \\
\hline 7 & Ranade et al, 2008[13] & $33 \%$ \\
\hline 8 & Dixit et al, 2009[9] & $14.6 \%$ \\
\hline 9 & Shankar et al, 2009[18] & 1 case \\
\hline 10 & Gupta et al, 2011[19] & 1 case \\
\hline 11 & Asha et al, 2013[20] & $20 \%$ \\
\hline 12 & Kaur et al 2015[21] & 1 case \\
\hline \multicolumn{3}{|c|}{ Table 1 } \\
\hline
\end{tabular}

The incidence of pyramidal lobe ranges from $7 \%$ to $77 \%$ as reported by various authors shown in Table 2 . In our case, the incidence is $18.75 \%$.

\begin{tabular}{|c|c|c|}
\hline Sr. No. & Author and Year & Incidence \\
\hline 1 & Braun et al, 2007[14] & $55 \%$ \\
\hline 2 & Ranade et al, 2008[13] & $58 \%$ \\
\hline 3 & Dixit et al, 2009[9] & $7.31 \%$ \\
\hline 3 & Won and Chung, 2002[15] & $76.8 \%$ \\
\hline 4 & Gupta et al, 2011[19] & 1 case \\
\hline \multicolumn{3}{|c|}{ Table 2 } \\
\hline
\end{tabular}

The basic mechanism of agenesis of isthmus can be explained embryologically. It may be due to the higher division of the thyroglossal duct, which result in absence of isthmus and two independent thyroid lobes. Agenesis of isthmus can be associated with dysorganogenesis related to developmental anomalies of thyroid gland such as absence of either lobes or presence of ectopic thyroid tissue. But in our study, there were no other associated anomalies of thyroid gland.

The agenesis of thyroid gland does not cause clinical symptoms by itself and most of the time the diagnosis is incidental due to existence of other thyroid pathology.[22]

It has also been observed that in such cases a band of connective tissue named levator glandulae thyroideae extends from the apex of right or left lobe or isthmus of the thyroid gland to the hyoid bone. This type of variations should be kept in mind during trans-thyroid tracheostomy procedures.[18] Tracheostomy can be potentially dangerous in such cases if a pre-procedure examination is not carried out as in securing invasive airway during emergencies, injuries or during unanticipated difficulty to impossible intubation. [23] Agenesis of isthmus can be diagnosed via scintigraphy, ultrasonography, computed tomography and magnetic resonance imaging. When absence of isthmus is suspected, the individual may be directed for a differential pathological diagnosis such as autonomous thyroid nodule, thyroiditis, primary carcinoma, neoplastic metastases and infiltrative diseases such as amyloidosis.

\section{CONCLUSION}

Agenesis of isthmus of thyroid gland is rare in humans. The incidence varying from $3 \%$ to $33 \%$. In our case, it is $12.5 \%$ with male-to-female ratio of 2: 1 . This agenesis can be explained embryologically due to higher division of the thyroglossal duct giving rise to two independent thyroid lobes with absence of isthmus. Agenesis of isthmus can be associated with other types of dysorganogenesis and hence in clinical practice when such a condition is diagnosed it is necessary to perform a differential diagnosis against other pathologies such as autonomous thyroid nodule, thyroiditis etc. So a brief knowledge of the anatomical variation of thyroid gland is essential for endocrinologists and surgeons for routine surgical procedures of the gland. The surgeon planning a thyroidectomy must be prepared to find variations. Absence of isthmus is a gift to persons needing immediate tracheostomy in order to manage the airway obstruction. Proper identification of vessels is also very important in order to avoid major complications. Hence, a thorough knowledge of the thyroid anatomy and its associated anatomical variations is very much essential, so that these anomalies are not overlooked in the differential diagnosis.

\section{REFERENCES}

[1] Dixit D, Shilpa MB, Harsh MP, et al. Agenesis of isthmus of thyroid gland in adult human cadavers: a case series. Cases J 2009;2:6640.

[2] Standring S, Herold E, Healy JC, et al. Gray's anatomy. 39th edn. Elsevier Churchill Livingstone 2005:560-4.

[3] Moore KL. The developing human: clinically oriented embryology. 4th edn. Toronto: W.B. Saunders. 1988.

[4] Moore KL, Persaud TVN. The pharyngeal apparatus. Chap- 10. The developing human clinically oriented embryology. $7^{\text {th }}$ edn. Saunders 2003:215-7.

[5] Larsen WJ. Development of head, the neck and the eyes and ears. Chap- 12. Human embryology. $2^{\text {nd }}$ edn. Hong Kong: Churchill Livingstone Inc 1997: p. 371.

[6] Standring S. Neck. Chap- 28. Gray's anatomy. The anatomical basis of clinical practice. $40^{\text {th }}$ edn. Spain: Elsevier 2008: p. 462.

[7] McMinn RMH. Head and Neck and Spine. Chap- 6. Last's anatomy regional and applied. $9^{\text {th }}$ edn. Singapore: Churchill Livingstone 1994:430-1.

[8] Larochelle D, Arcand P, Belzile M, et al. Ectopic thyroid tissue--a review of the literature. J Otolaryngol 1979;8(6):523-30.

[9] Pastor VJF, Gil VJA, De Paz Fernandez FJ, et al. Agenesis of the thyroid isthmus. Eur J Anat 2006;10(2):83-4.

[10] Harjeet A, Sahni D, Jit I, et al. Shape, measurements and weight of the thyroid gland in northwest Indians. Surg Radiol Anat 2004;26(2):91-5.

[11] Gangbo E, Lacombe D, Alberti EM, et al. Trisomy 22 with thyroid isthmus agenesis and absent gall bladder. Genet Couns 2004;15(3):311-5.

[12] Marshall CF. Variations in the form of the thyroid gland in man. J Anat Physiol 1895;29(Pt 2):234-9.

[13] Ranade AV, Rai R, Pai MM, et al. Anatomical variation of the thyroid gland: possible surgical implications. Singapore Med J 2008;49(10):831-4.

[14] Braun E, Windisch G, Wolf G, et al. The pyramidal lobe: clinical anatomy and its importance in thyroid surgery. Surg Radiol Anat 2007;29(1):21-7. 
[15] Won HS, Chung IH. Morphologic variations of the thyroid gland in Korean adults. Korean J Phys Antropol 2002;15(2):119-25.

[16] Harjeet A, Sahni D, Jit I, et al. Shape, measurements and weight of the thyroid gland in northwest Indians. Surg Radiol Anat 2004;26(2):91-5.

[17] Kulkarni MN, Kadam JY. Absence of the thyroid isthmus. J Anat Soc Ind 2001;50(1):97.

[18] Sankar KD, Bhanu PS, Susan PJ, et al. Agenesis of isthmus of thyroid gland with levator glandulae thyoideae. Int J Anat Vari 2009;2:29-30.

[19] Gupta R, Single RK. Multiple Anomalies in the morphology and the blood supply of the thyroid gland: a case report. J Clin Diagn Res 2011;5(8):1634-6.
[20] Asha S, Dixit D, Shirol VS, et al. Study of absence of isthmus of thyroid gland with its developmental and surgical implications in adult human cadavers- a case series. Med Inn 2013;2(1):50-2.

[21] Kaur HS, Kumar U, Bajwa SJS, et al. Absent thyroid isthmus: embryological and clinical implications of a rare variation of thyroid gland revisited. Thyroid Res Pract 2013;10(2):80-2.

[22] Schanaider A, de Oliveira PJ. Thyroid isthmus agenesis associated with solitary nodule: a case report. Cases J 2008;1(1):211.

[23] Bajwa SS, Sehgal V. Anaesthesia and thyroid surgery: The never ending challenges. Indian J Endocrinol Metab 2013;17(2):228-34. 